Philosophy and Progress: Vols. LXI-LXII, January-June, July-December, 2017 ISSN 1607-2278 (Print), DOI : https://doi.org/10.3329/pp.v61i1-2.44206

\section{LOCKE'S THEORY OF IDEAS: A CRITICAL EXPOSITION}

\section{Refat-E-Rubaia}

\begin{abstract}
John Locke, Bishop Berkeley and David Hume are the pioneers of modern British Philosophy during $17^{\text {th }}$ and $18^{\text {th }}$ centuries. Among them, John Locke's epistemological work is one of the greatest defenses of modern empiricism. He attempts to determine the limits of human understanding and seeks to clear the ground for future developments by providing a theory of knowledge compatible with the study of human nature. In his discussion the term 'ideas' plays an important role. To understand Locke's empiricism, one must realize what he means by 'ideas'. For Locke, ideas are all signs which represent the external world of physical objects and the inner world of consciousness. However, in his book, An Essay Concerning Human Understanding, he discusses 'ideas' in details but he does not provide a sufficiently clear account of the nature of ideas. This paper is an attempt to give a critical exposition of John Locke's theory of ideas in which I will try to show that his explanation about the nature of idea is not sufficient enough to establish the theory of ideas he presented.
\end{abstract}

\footnotetext{
* Lecturer, Department of Philosophy, University of Dhaka Email: refat.rubaia@gmail.com
}

\section{Introduction}

Locke refutes Descartes' theory of innate ideas and formulates his empirical theory of knowledge. The basis of his empirical theory of knowledge is the notion of 'ideas'. According to Locke, the process of acquiring knowledge is experience but the main element of knowledge is 'idea', an immaterial element which is physically imperceptible. He claims that what we perceive are not the objects but an idea of the object in the real world and idea is not a material but an immaterial thing. Thus, what we perceive is just an intermediary between the object perceived and the perceiver.

Locke's primary concern is about the basic problem of knowledge. i.e., the source of knowledge and understanding. He explains how human mind works to transmit experiences with other bits of knowledge to categorize and interpret future information. He presents 'ideas' as a basic unit of human understanding and claims that we can break all our experiences into these fundamental elements. Locke believes that through a three-folded process, i.e. sensation, reflection and judgment, human mind acquires knowledge. At the initial stage of this process, mind picks up raw materials to modify them into knowledge. He terms these raw materials as 'ideas'. As he says:

I must here ... beg pardon of my reader for the frequent use of the word idea, which he will find in the following treatise. It being that term which, I think, serves best to stand for whatsoever is the object of the understanding when a man thinks...

\section{"Ideas" Defined}

Locke argues that at birth the mind is a tabula rasa (blank sheet of paper) on which experience gradually writes its impressions through the five senses. He is very much inclined 
to use ideas as a source of knowledge by arguing that ideas are supplied to us by our experience. We may try to understand what he means by ideas from his remarks,

... I have used it to express whatever is meant by phantasm, notion, species. Or whatever it is which the mind can be employed in thinking and I could not avoid frequently using it. $^{2}$

For Locke, ideas are the first subject of investigation. He considers ideas as the basic necessity of knowledge by arguing that knowing something is similar to having ideas. He inquiries about the source of ideas and observes that experience (sensation and reflection) is the only source of these ideas as well as human knowledge. So, it can be said that cognitive process depends on both mind and the external world, and the connection between them is ideas. External world supplies ideas to the mind through several stages and thus knowledge evolves. By rejecting the existence of innate ideas, Locke tries to prove that before receiving ideas mind remains passive but when mind receives ideas it becomes active.

In Locke's view, ideas and the things, we perceive, are not the same. Several external objects strike in our sense organs and our mind gets ideas, but it necessarily doesn't mean that those certain objects that we perceive are in our mind. Rather, Locke believes, 'ideas' are the 'representations' of certain objects we perceive and they prevail in our mind. Through the ideas mind acquires knowledge. Therefore, ideas are the 'representatives' of external objects in mind. It is evident that mind knows things not immediately, but by the interventions of the ideas it has. Locke believes in the representative nature of ideas. In his words:

Since the things that the mind contemplates are none of them, besides the mind itself, present to the understanding, it is necessary that something else, as a sign or representation of the thing it considers, should be present to it; and these signs or representations are ideas. ${ }^{3}$

This view of Locke that ideas are the 'representations' of external objects in our mind and through this representation mind gathers knowledge has been termed as 'representative realism'. During the interaction between mind and the external world, sensation through external objects is the cause and ideas generated in the mind are the effects. Locke, therefore, is not only a realist, but also a proponent of the causal theory of perception. Causal theory of perception precisely is the view that our sense-perceptions are the mental effects of the actions upon our bodily senses of physical objects which are their causes. It consists roughly of the claim that, if a subject $S$ sees an object $\mathrm{O}$, then $\mathrm{O}$ causes $\mathrm{S}$ to have a visual experience. Our sense-perceptions and physical objects are 'two very different things. As Richard Schacht holds,

It being one thing to perceive and know the idea of white or black, and quite another to examine what kind of particles they must be, and how to make any object appear white or black. $^{4}$

Locke argues that we can never really form a complete picture of an object in our minds that matches the object itself as it really is in the material world. We can only have ideas about that object. For example, suppose if I have a slice of cheese in my hand, I can look at the cheese, or smell the cheese and then I can take a taste of it. My mind will develop ideas about that cheese from my experience with it. Here Locke will argue that my thought of what this slice of cheese is can only be a representation of the reality of the cheese exactly is. When we learn about an object with our senses by looking at it, touching it, smelling it, hearing it, or tasting it, we can gain 
information about what the object is like, even if it doesn't give us the ultimate truth about it.

\section{Division of Ideas}

Locke divides ideas into two groups: Simple and Complex. In his words: "The better to understand the nature, manner and extent of our knowledge, one thing is carefully to be observed concerning the ideas we have; and that is, that some of them are simple and some complex." "Human mind at first receives ideas that are uncompounded in nature. Locke terms them as simple ideas. Simple ideas, according to him, are the basic unit of human knowledge and mind receives them in a very passive condition which involves no selection process. Whatever comes into the domain of perception mind captures the ideas involved with them. It is the power of human mind through which ideas arranges, combines, discerns, abstracts. By analyzing our thoughts, Locke attempts to show that we will only get the objects of sensation and the operations of our mind.

Simple ideas are uncompounded and indivisible and contains one uniform conception in the mind. These ideas are provided by our senses. Simple ideas can be obtained by using one sense organ (for example, we get the idea of whiteness through the sight) or by using more sense organ (we get the idea of extension through the sense of sight and touch) or, by using all our senses (idea of existence, unity, power and so on).

On the other hand, complex ideas evolve when we use simple ideas for joining, discerning or substituting. Complex ideas are compound in nature and they involve the act of mind. Our mind joins ideas, brings them together, and abstracts them from all of our ideas that accompany them in their real existence. If we analyze complex ideas, we will get simple ideas. So, logically simple ideas are prior to the complex ones.
For example, the general idea of 'Triangle' is a complex idea as it means a plain figure bounded by three straight lines or the idea of 'Unicorn' is complex one as it evolves from the ideas of 'horse' and 'single spiral horn'. Complex ideas are the sum up of simple ones and they are closer to knowledge than simple ideas.

\section{Advanced Division of Ideas}

In order to make the concept of 'ideas' clearer Locke again divides ideas into four types: clear, obscure, distinct and confused ideas. Those ideas are considered as clear ideas which evolve in the mind by consistent and well-ordered perception of external object. As Locke writes:

A clear idea is that where the mind has such a full and evident perception as it does receive from an outward object operating duly on a well-disposed organ. ${ }^{7}$

Locke thinks that the idea of substance is a confusing one, because our mind doesn't get the idea of substance through a full and evident perception. Though the idea of substance has a very important role to play in philosophical discussion, we don't get a direct apprehension of substance either in our sensation or in reflection. This kind of idea is an obscured idea. A distinct idea is that idea wherein mind perceives a difference from all others, while a confused idea is the one which is not sufficiently distinguishable from another, from which it ought to be different." 8 The idea of a pineapple can be considered as distinct one as it can be easily differentiated from the idea of an apple by tasting it or by seeing it.

However, Locke's notion about some other ideas such as pure space, motion, existence, unity, power and cause and effect are not very clear either. He says that we can get the idea of space by both our sight and touch. But no one can say he/she 
has experienced 'pure space' either by sight or by touch. Only we perceive certain objects of varying sizes. Similarly, we have the idea of existence, but we never get this idea from the act of sensation or perception. The idea of causation also goes beyond observation with senses. Because we never get this idea by observing things and receiving their existence from some other being or we don't get the idea of effect by observing something in some state, and then in another state, in the presence of something else. ${ }^{9}$ Thus, Locke's explanation about ideas of these sorts is questionable and his thesis (every idea is derived either from the act of sensation or reflection) need to be reconsidered.

\section{Idea's process of cognition}

The mind of an infant is like an empty cabinet on which nothing has been imprinted, or a piece of white paper on which nothing has been written. Locke thinks mind has the power to compound, compare, relate and make abstractions from the simple ideas which it has received in experience; once the mind has materials to work upon, it takes an active part in the process of obtaining genuine knowledge.

Using the ability of five senses (sight, smell, hearing, taste, touch) human mind gathers sensations such as heat, cold, hard, soft etc. and becomes familiar to them. Here becoming familiar would be similar to that of knowing. Sensation is the external source of knowledge. After receiving these ideas by senses, human mind starts processing them and this operation includes perceiving, thinking, doubting, remembering, comparing, compounding, reasoning, naming and abstracting. It seems that this is a continuous operation of the mind which Locke refers as 'reasoning', 'thinking', or, 'understanding, ${ }^{10}$ On the other hand, reflection is the internal source of knowledge or acts of our mind. Everything we know, everything we believe, every thought we can think is made up of ideas of sensation and reflection and nothing else. After the stage of reflection when the relation between ideas is already detected with senses, these relations are used in the form of utterances, written sentences, propositions-in a word knowledge.

For Locke, all of our ideas are not derived from sensation. We have also the idea of perception and this is the idea of a mental process or operation. We acquire various ideas of sense through perception, which provide the materials for our other mental operations. Locke observes that in perception our sensations are often colored by our judgements, so that our perceptions to this extent are not strictly identical with our sensations. He tends to regard perception as the passive reception of simple ideas, and commonly uses the terms 'perception' and 'sensation' synonymously. ${ }^{11}$

Locke believes that knowledge evolves through the operation of a number of other faculties upon the simple ideas collected by the act of sensation and perception. The first mental operation is considered as 'retention', which is simply the powers of keeping in mind some acquired ideas. Specifically, knowledge retention means capturing knowledge in the mind so that it can be used later. The next operation is 'discerning and distinguishing' between various simple ideas. Locke mention it as, 'the comparing them one with another in respect of extent, degrees, time, place, or any other circumstances'. These two mental operations ('retention' and 'discerning and distinguishing') does not result in any sort of knowledge. Next operation is 'composition' where mind puts together several of those simple ideas it has received... and combined them into complex ones'. The final operation is mentioned as 'abstraction'. Abstraction involves the use of words. Locke holds that all our general ideas are simply 
abstractions from various particular ideas we have acquired through perception.

\section{Shortcomings of Locke's theory of ideas}

Locke admits that he has no special liking for the term 'idea', but after working with various terms he has found this the most convenient of all those which were possible. Sense-data, memories, images, concepts, abstract ideas differ from each other greatly, and to call them all by the same name is to invite confusion. Locke wants a comprehensive term to embrace all the immediate objects of the understanding. But his use of the word 'idea' in this exceedingly wide manner leads to ambiguity. Gilbert Ryle points out how Locke throws new light where darkness was before. Ryle holds that the analysis of the concepts of knowledge, probable judgement, belief, guesswork, faith, sensation, perception, discernment, comparison, abstraction, and the rest, is not laboratory work -though what the nature of the process is Locke does not directly elucidate. Therefore, Ryle concludes that the central and official teaching of Locke, 'The new way of ideas', is partly and disastrously the product of just the sort of causal hypothesis which he formally rejected. Being impressed by Locke's view, Ryle admits that Locke sometimes uses the term 'ideas' to denote 'images' or 'pictures' and sometimes as an act of thinking about something. ${ }^{12}$

Locke's empiricism has been criticized as insufficient in accounting for knowledge and in explaining its foundation. Indeed, it is clear that Locke conceives 'ideas' as the foundation of his empiricist theory. Henry Lee criticize Locke's theory of ideas by arguing that Locke's preoccupation with ideas makes his theory of knowledge too far from reality as he finds ideas as the basement of all knowledge. ${ }^{14}$ Many critics of An Essay were profoundly disturbed by Locke's usage of the term 'idea'. Some of the misunderstandings which arises between Locke and his critics come undoubtedly because of the readers unfamiliarity with this term. ${ }^{15}$ Milner compares this language with the ordinary language by arguing that Locke's An Essay would be easier and intelligible, if he had made use of other terms and not filled every page almost with the mention of ideas. John Norris in his Cursory Reflections raises the crucial question concerning the key term 'idea', namely 'what sort of entities are ideas?' Norris wants to inquire what kind of things these ideas are in essence: Are they in the first-place real beings or not? ${ }^{15}$

Norris is certain that ideas are real beings for Locke in the sense that they have 'real properties' and are really different from one another, and representing things really different in nature. But he questions- are they substance, or are they modifications of substance? Norris believes that Locke could not have meant ideas to be modifications of substances, since modifications cannot be 'representative' of substances, as ideas must be for Locke. Then Norris questions "are they material or immaterial?" And he believes that they cannot be material. ${ }^{16}$ In his later work, An Essay Towards the Theory of the Ideal or Intelligible World Norris argues that, if Locke means that material objects send ideas to the mind, then he has 'derived our Ideas from a false original,' but if all he means is that sensible objects do by the impression which they make upon our outward senses serves to excite ideas in our minds,' then there is nothing very dangerous or original in Locke's doctrine. $^{16}$

Locke holds that thoughts and ideas are identical and so there can be no unconscious thoughts. Following this question Roger Scruton holds: 
The Essay is the fruit of a lifetime's interest in philosophy and the foundations of natural science. It is a vast, disorganized and repetitious work, written in a sinuous style, full of hidden subtleties and difficult to grasp in its totality. The arguments are directly opposed to many of the most important tenets of Cartesian rationalism. Yet the language of the book is through and through influenced by Descartes and can be read, from one point of view, as an extended critical reflection on the crucial term 'idea', which Locke took from Descartes with the intention of freeing it from the rationalist connotations. Ideas are the immediate objects of the understanding...And the first thing to note about ideas, according to Locke, is that they all, without exception, come to us from experience. ${ }^{18}$

Locke's thinking is very much similar to Descartes as Descartes uses the term 'think' similar to all kind of mental events. Similarly, Locke have used 'ideas' as 'perception'. Here 'perception' stands for understanding. In the introduction to An Essay Locke questions what time a man has first any idea, is to ask, when he begins to perceive; having ideas, and perception, being the same thing. J. Bennett thinks that Locke's double use of 'idea' is not a mere terminological nuisance: It embodies his substantive mistake, shared with Berkeley and Hume and others in the empiricist tradition of assimilating the sensory far too closely to the intellectual. ${ }^{19}$

Another critic C. B. Martin points out that some mistaken interpretations of Locke create difficulties in understanding his views. There is an interpretation that Locke assumes without question that all words are names of ideas. This is rather a misinterpretation we would say, because it is done without including some chapters of the Essay. In book III, chapter 5II, of the Essay, "Of particles" we see Locke discusses about words that "are not truly by themselves the names of ideas" such as 'is', 'is not', and 'but'. ${ }^{20}$ Martin also holds that Locke thinks that ideas are mental "things" is also a misunderstanding. This misunderstanding springs as Locke considers ideas as whatsoever is the object of the understanding when a man thinks. Locke never said that ideas could be the parts of human mind. Generations of students used to study Locke's philosophy by studying the Pringle-Pattinsons edition. That shorten ones lessens the strength or effect of Locke's philosophy which were not sufficient enough to understand Locke's thinking.

\section{Conclusion}

Locke does not formally define the concept of ideas. He takes it as an undefined term and uses it as a fundamental concept in his system. Locke set out to offer an analysis of human mind and its acquisition of knowledge. He offers an empiricist theory according to which we acquire ideas through our experience of the world. The mind is then able to examine, compare and combine these ideas in different ways. Knowledge consists of a special kind of relationship between different ideas. Although renowned for its new approach to the description of mental operations, the philosophy of Locke is designed as a critique of knowledge. It can be said from the above discussion that Locke implicitly presupposes a determined conception about the nature of ideas. Mostly An Essay depicts the view that ideas are 'real beings'. Locke thinks of ideas as specifically material beings, and not immaterial entities existing in the mind of God, as the neo-Augustinian view holds. However, the view that ideas are real beings is thought to have disastrous epistemic consequences, as it places subjects behind a veil of ideas from where knowledge of a mind-independent becomes impossible. In this same point Locke's theory of ideas can be attacked by referring it as- 'a shadowy kind of beings intermediate between the thought, and the object of thought. ${ }^{21}$ 


\section{References}

1. M. Cranston, (1965). Locke's Essay Concerning Human Understanding, London: The Macmillan Company, p. 27.

2. Ibid., p. 27.

3. P. Nidditch, (Eds.). (1995). An Essay Concerning Human Understanding, Oxford: Oxford Clarendon Press, p. 21.

4. Richard. Schacht, (1984). Classical Modern Philosophers: Descartes to Kant, England: Routledge \& Kegan Paul Ltd, p. 81.

5. Cranston, Op. cit., p. 70.

6. Locke discussed about simple ideas in Book 2, chapter 1-5. He observes that simple ideas come to our mind separately, prior to complex ideas from psychological point of view.

7. Ibid., p. 41.

8. Ibid., p. 42.

9. Schacht, Op. cit., p. 86.

10. Samuel. Stumpf, (1975). Socrates to Sartre: A History of Philosophy, New York: McGraw Hill Book company, p. 276.

11. Schacht, Op. cit., p. 86.

12. R. Aaron, John Locke, Oxford: Oxford Clarendon Press,1937, p. 99.

13. H. Lee, (1978). Anti-Scepticism, New York: Garland Reprint, p. preface.

14. Gilbert. Ryle, Locke On the Human Understanding, Oxford: Oxford University Press, 1993, p. 14.

15. John. Yolton, (1956). John Locke and the Way of Ideas, oxford: Oxford University Press, p. 87.

16. J. Norris, (1961). Cursory Reflections Upon a Book Call'd An Essay Concerning Human Understanding, California: The Augustan Reprint Society, p. 22.
17. J. Norris, J., \& Richard, Acworth. (Eds.). (1962). An Essay Towards the Theory of Ideal or Intelligible World, Detroit: University of Michigan, p. 37.

18. Roger. Scruton, (1995). A Short History of Modern Philosophy: From Descartes to Wittgenstein, Routledge: London and New York, p. 82.

19. J. Bennett, (1971). Locke, Berkeley, Hume: Central Themes, Oxford: Clarendon Press, p. 25.

20. C, B. Martin, \& D, M. Armstrong, (Eds.). (1960). Locke and Berkeley: A Collection of Critical Essays, London, Macmillan and company Ltd., p. 102.

21. R, Derek. (Eds.). (2001). Essays on the Intellectual Powers of Man: A Critical Edition, Edinburgh: Edinburgh University Press, p. 136. 